\title{
NUTRIENT BALANCE OF PHOSPHORUS IN LONG-TERM FIELD EXPERIMENT
}

\author{
Štěpánka Matějková1, Markéta Mayerová1, Lenka Odstrčilová², \\ Jitka Kumhálová ${ }^{3}$
}

\footnotetext{
${ }^{1}$ Team of Agricultural Soil Science and Pedobiology, Division of Crop Management System, Crop Research Institute, Drnovská 507, 16106 Prague, Czech Republic

${ }^{2}$ Experimental Station Hněvčeves, Division of Experimental Stations, Crop Research Institute, 50315 Nechanice, Czech Republic

${ }^{3}$ Department of Machinery Utilization, Faculty of Engineering, Czech University of Life Sciences Prague, Kamýcká 129, 16521 Prague, Czech Republic
}

Link to this article: https://doi.org/10.11118/actaun.2021.060

Received: 14. 7. 2017, Accepted: 7. 12. 2021

To cite this article: MATĚJKOVÁ ŠTĚPÁNKA, MAYEROVÁ MARKÉTA, ODSTRČILOVÁ LENKA, KUMHÁLOVÁ JITKA. 2021. Nutrient Balance of Phosphorus in Long-Term Field Experiment. Acta Universitatis Agriculturae et Silviculturae Mendelianae Brunensis, 69(6): 677-683.

\begin{abstract}
Phosphorus is a major nutrient for plants and the determination of available phosphorus in soil is necessary for agricultural practices. Phosphorus balance in soil was assessed in the long-term stationary experiment at Hněvčeves from 1980 to 2015. The results indicate that the phosphorus balance was significantly influenced by the doses of phosphorus in mineral fertilization and farmyard manure. The most well balanced balance of phosphorus in soil was achieved at the plots with low doses of phosphorus applied in mineral fertilization and farmyard manure. Negative phosphorus balance was found out in the combination without the dose of phosphorus in both fertilizers. On the contrary, phosphorus surplus was indicate in the combination with very high level of phosphorus dose in mineral fertilization and medium level of phosphorus dose in farmyard manure or in the combination with medium level of phosphorus in mineral fertilization and very high level of phosphorus in farmyard manure. Very high positive correlation of phosphorus contents were found in plants to yield. Data about phosphorus balance can help to modify phosphorus fertilization doses for subsequent crops and optimize production inputs.
\end{abstract}

Keywords: available phosphorus, soil, balance, yield, crops, mineral fertilization, farmyard manure

\section{INTRODUCTION}

Phosphorus (P) together with nitrogen and potassium are an essential element classified as macronutrients in soil and are needed by all plants (Busman et al., 2009; Shi et al., 2015). Most plants contain P in concentrations varying between $0.1 \%$ and $0.4 \%$, and its significance in stimulating root growth and accelerating plant ripening was proven (Ott and Rechberger, 2012).

$\mathrm{P}$ is one of three nutrients generally added to soils in fertilizers that can considerably affect the yield level and yield stability of many crops (Usherwood and Segars, 2001; Yutong et al., 2016). Some authors found out P soil-surface balance may range from negative values to more than $200 \mathrm{~kg} \cdot \mathrm{ha}^{-1}$ depending on the farming practices (Halberg, 1999; Hooda et al., 2001; Steinsham et al., 2004). Since 1990, the use of mineral fertilizers, mainly phosphate and potassium fertilizers has dropped sharply in the Czech Republic because of economic reasons (Voplakal et al., 2001). This decrease had a negative impact on the levels of available nutrients in the soil, which determine the quantity and quality of the yield. Voplakal et al. (2001) noted that total P in 
the soil of the Czech Republic contained from 1.5\% to $4.5 \%$ of available P. Only a part of P in the soil is dissolved in the soil solution (Raclavská et al., 2008). Available $P$ is very low in the soil of the Czech Republic, about $1 \%$ of total $\mathrm{P}$ and its concentration in the soil solution is from $0.1 \mathrm{mg} . \mathrm{l}^{-1}$ to $1 \mathrm{mg} . \mathrm{l}^{-1}$, which is the lowest of all the essential nutrients needed for plant growth. $\mathrm{PO}^{-4}$ is a form of $\mathrm{P}$, which is accepted by plants and microbes (Raclavská et al., 2008).

Stewart and Tiessen (1987) demonstrated soil fertilization with organic materials was significant for increasing of available $\mathrm{P}$ in soil. According to Chater and Mattingly (1980) the content of total $\mathrm{P}$ in arable soil is generally little affected by the long-term fertilization practices. Various fractions of soil P respond more to contrasting treatments (O'Halloran et al., 1987) and show large seasonal variation (Tate et al., 1991; Magid and Nielsen, 1992). Čermák et al. (2007) studied P balance in soil of the Czech Republic and found out P balance is slightly negative. According to the Eurostat (2017) high positive $\mathrm{P}$ balance is in the Mediterranean Islands, Cyprus and Northwest-Europe while negative balance is in Italy and many states of the Central and Eastern Europe.

The long-term field trials provide an important source of information demonstrating the effects of continuous and specific rates of application of fertilizers over many years on soil properties and crop yields. Based on the results from these long-term experiments, it is possible to calculate nutrient balance and thereby determine optimal nutrient application rates for sustainable good quality crop production (Čermák and Smatanová, 2012). Macháček and Kunzová (2016) demonstrated use of nutrient balances obtained from the longterm experiments for further recommendations of changes in agronomic technology to decrease of nutrient losses. They calculated $\mathrm{P}$ balance in the long-term field experiment as the simple calculation, the difference between total inputs of fertilizers and total nutrient uptake by crops. Beegle and Lanyon (2015) used the same method for the evaluation of $\mathrm{P}$ balance. They defined a positive balance as an accumulation of $\mathrm{P}$, while a negative balance as a depletion of Čermák and Smatanová (2012) deal with P balance at the 13 experimental sites in the Czech Republic, where they described phosphorus offtake and input as well balanced at low levels of $\mathrm{P}$ fertilization. According to these authors, increasing $\mathrm{P}$ application rates leads to increasing the P balance surplus.

Current analyses of the nutrient balance do not contain the analyses of $\mathrm{P}$ utilization for the different crops at the application of different doses of the mineral and organic fertilization in soil and climate conditions. Our paper is based on the results of the long-term experiment, which is focused on monitoring of crop yields at different levels of fertilization in different crop rotations. Goal of the analysis was to assess the impact of the application forms and levels of supplied $\mathrm{P}$ on the stability of $\mathrm{P}$ in the soil and its availability for different agricultural crops and impact on the crop yield.

\section{MATERIALS AND METHODS}

\section{Site Description of Field Experiment, Soil and Crop Sampling}

The experimental data for this study were obtained from the polyfactorial nutritional experiment. According to Cochran and Cox (1957), a central scheme of the second order design in incomplete blocks was used for experiment. The trial consisted of 56 plots $5 \times 12 \mathrm{~m}$, designed in 4 rows. Within the scheme, the influence of 6 independent factors was tested (Tab. I). We used only 2 factors, mineral fertilization of $\mathrm{P}$ and farmyard manure fertilization (FYM) for P balance evaluation.

I: Crop rotation and a list of doses of fertilizers including factor levels

\begin{tabular}{|c|c|c|c|c|c|c|c|}
\hline \multirow{5}{*}{ Year } & \multirow{5}{*}{ Crop } & \multirow{5}{*}{$\mathrm{N}$ total } & \multirow{5}{*}{$\mathrm{Ca}$} & $\mathrm{P}$ in mineral fertilizer & $\mathrm{P}$ in FYM & \multirow{4}{*}{$\mathrm{K}$} & \multirow{4}{*}{$\begin{array}{l}\text { Mean sowing } \\
\text { rate on } \text { ha }^{-1}\end{array}$} \\
\hline & & & & Level of factors & Level of factors & & \\
\hline & & & & $-2.4 /-1 / 0 / 1 / 2.4$ & $-2.4 /-1 / 0 / 1 / 2.4$ & & \\
\hline & & & & Doses of fertilizers & Doses of fertilizers & & \\
\hline & & & & kg.ha ${ }^{-1}$ & $10^{3} \mathrm{~kg} \cdot \mathrm{ha}^{-1}$ & kg.ha-1 & \\
\hline 1980 & sugar beet & 150 & - & 0/29/50/71/100 & 0/23/40/57/80 & 150 & $85.10^{3}$ \\
\hline 1981 & spring barley & 60 & - & 0/23/40/57/80 & - & 50 & 4.5.10 \\
\hline 1982 & alfalfa + oat underseeding & 40 & - & 0/35/60/85/120 & - & 100 & 4.5.10 \\
\hline 1983 & alfalfa without fertilization & - & - & - & - & - & $22.5 \mathrm{~kg}$ \\
\hline 1984 & winter wheat & 100 & - & $0 / 23 / 40 / 57 / 80$ & - & 70 & 4.5.10 \\
\hline 1985 & silage maize & 170 & - & 0/29/50/71/100 & $0 / 23 / 40 / 57 / 80$ & 150 & $100.10^{3}$ \\
\hline 1986 & winter wheat & 125 & - & $0 / 23 / 40 / 57 / 80$ & - & 70 & 4.5.10 \\
\hline 1987 & spring barley & 90 & 3500 & 0/23/40/57/80 & - & 50 & $4.5 .10^{6}$ \\
\hline
\end{tabular}


II: Overview of the general arrangement of combinations of fertilization factors and their relative levels

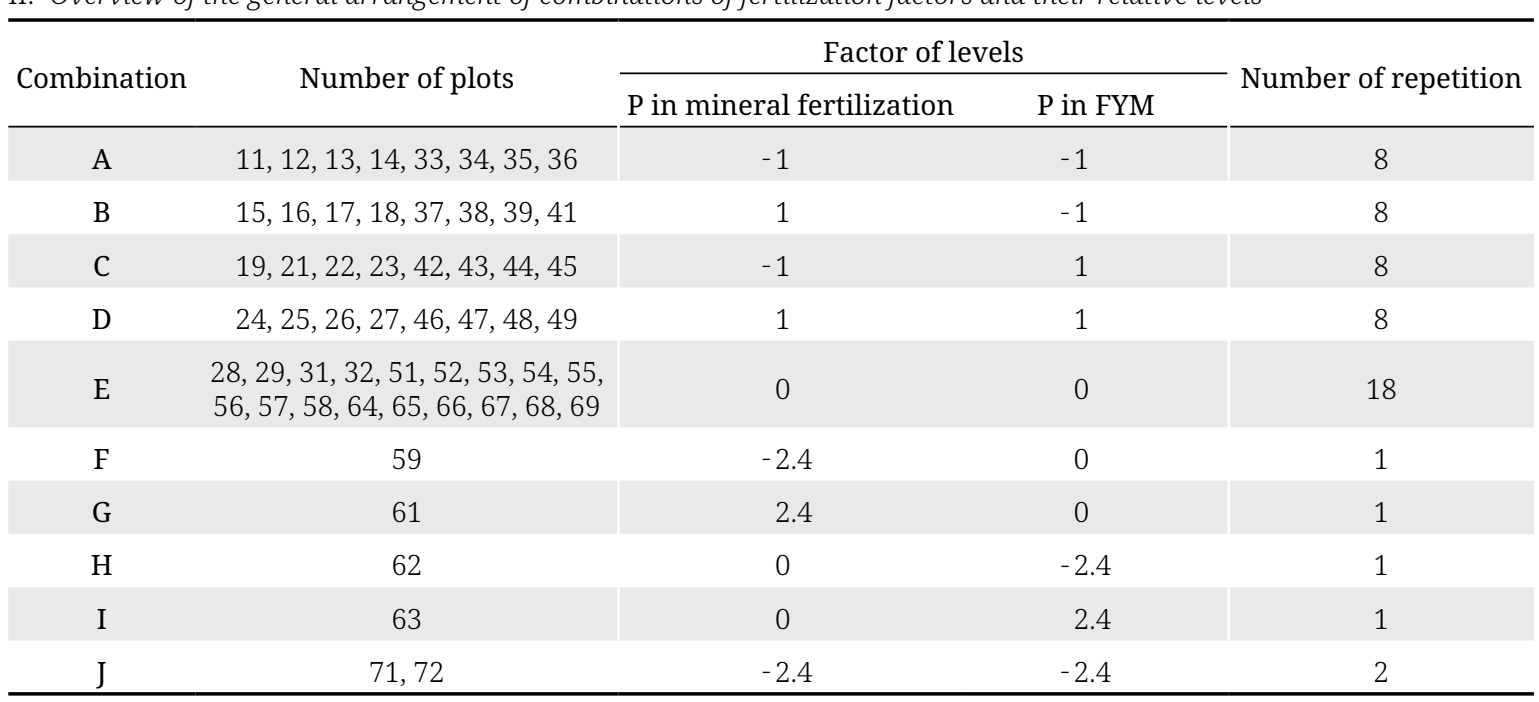

Note: Factor of levels: - 2.4 - zero level, - 1 - low level, 0 - medium level, 1 - high level, + 2.4 - very high level

The polyfactorial trial has been conducted

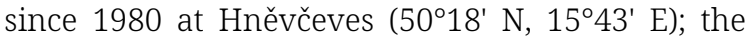
experimental station of the Crop Research Institute in the sugar beet growing region of the Czech Republic. Average annual precipitation is $589 \mathrm{~mm}$ and average temperature is $8.9^{\circ} \mathrm{C}$. Elevation is $265 \mathrm{~m}$ a.s.l. The experimental field is represented by Haplic Luvisol soil. 20-year average of nutrient content in soil from 1990 to 2009 was 71 mg P.kg-1,

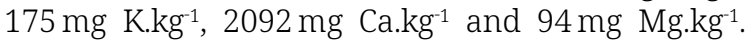
Soil reaction was for $\mathrm{KCl} 5.1$ and $\mathrm{H}_{2} \mathrm{O} 6.87$ (www. vurv.cz, 2017). Our experiment included data from 1980 to 2015. Tab. I and II show 8-years crop rotation, an overview of doses of fertilization with 5 graded levels $-2.4,-1,0,1,2.4$ and soil tillage from 1980 to 1987. 5 levels corresponding to each factor were set up in a manner that medium level reflected standard agricultural cropping practice, specific for each crop-plant, and the highest level was supposed to limit plant growth by the excess of the nutrient (Madaras and Lipavský, 2009). Zero level means no use of the fertilizer. Between the medium and extreme levels, two other levels (higher, lower) were set up, of which 'higher' was supposed to be optimal or close-to-optimal in order to satisfy crop demands and reach maximum yield. The eight years crop rotations contain 50 percent of cereals, 12.5 percent of root crops and 37.5 percent of fodder crops.

The soil samples, taken from depths of $0-20 \mathrm{~cm}$, were analysed by the Mehlich III extraction (Hraško et al., 1962) for content of available nutrient as P, Ca, $\mathrm{K}, \mathrm{Mg}$ and total content of $\mathrm{N}$.

Plant samples were taken from all variants shortly before harvest. Plants were analysed for $\mathrm{N}$ content by the Kjeldahl method (ČSN EN ISO 5983-1) and total nutrient content of $\mathrm{K}, \mathrm{P}, \mathrm{Mg}$ and $\mathrm{Ca}$ in the dry matter by the method of wet combustion.

\section{Phosphorus Balance Calculation}

$\mathrm{P}$ balance at given combination of factor levels was calculated as the difference between the value of supplied P to the soil only in mineral fertilizers and FYM and taken P by plants from the soil, which is stored in a dry matter of harvested crops in main product. Straw was taken off from all plots away. Only beet tops were ploughed into the soil in all combinations with observed fertilizer factors. $\mathrm{P}$ leaching and atmospheric deposition was not taken into account. A combination of factors for the application of fertilizers is given in Tab. II. FMY was only applied in two years, in 1983 and 1986 and always before growing of the sugar beet and silage maize. P balance was calculated from 1980 to 2015.

\section{Statistical Analysis}

Basic statistic and Pearson's correlations between yield, fertilization and content of $\mathrm{P}$ in plant dry matter were calculated using Statistica 12 (StatSoft Inc., Tulsa, USA) procedure.

\section{RESULTS AND DISCUSSION}

The obtained results of soil P balance (1980-2015) confirmed statistically significant effect of selected 10 combinations of mineral and organic fertilization by $\mathrm{P}$ on its balance in the soil. High positive correlation was found between observed levels of supplied $\mathrm{P}$ in fertilization and its balance in the soil ( $r=0.94 ; p<0.05)$. The combination $\mathrm{H}$ was the most balanced $\left(2 \mathrm{~kg} \cdot \mathrm{ha}^{-1}\right)$. The combination $\mathrm{G}$ had the highest P balance during the years ( $\left.41 \mathrm{~kg} \mathrm{ha}^{-1}\right)$. Negative $\mathrm{P}$ balance in the soil was confirmed in the combination of fertilizer doses J (-17 kg.ha-1) and F (-17 kg.ha $\left.{ }^{-1}\right)$ (Tab. III). Mitas (2005) presented similar conclusions for the balance of $\mathrm{P}$ in arable soil. According to the author, combination without fertilization had the negative balance; combination 
III: P balance in $\mathrm{kg}$.ha-1 for each crop for a given combination of factors during the years 1980 to 2015

\begin{tabular}{|c|c|c|c|c|c|c|c|}
\hline \multirow[b]{2}{*}{ Combination } & \multicolumn{6}{|c|}{ Crops } & \multirow{2}{*}{$\begin{array}{l}\text { Average P balance } \\
\quad(1980-2015)\end{array}$} \\
\hline & $\begin{array}{l}\text { sugar } \\
\text { beet }\end{array}$ & $\begin{array}{l}\text { spring } \\
\text { barley }\end{array}$ & $\begin{array}{c}\text { alfalfa } \\
+ \text { oat underseeding } \\
\end{array}$ & $\begin{array}{l}\text { alfalfa without } \\
\text { fertilization }\end{array}$ & $\begin{array}{l}\text { winter } \\
\text { wheat }\end{array}$ & $\begin{array}{l}\text { silage } \\
\text { maize }\end{array}$ & \\
\hline A & $\frac{8}{(52)}$ & $\frac{-2}{(23)}$ & $\frac{4}{(35)}$ & $\frac{-32}{(0)}$ & $\frac{-5}{(23)}$ & $\frac{14}{(52)}$ & $\frac{-4}{(31)}$ \\
\hline B & $\frac{38}{(94)}$ & $\frac{26}{(57)}$ & $\frac{36}{(85)}$ & $\frac{-32}{(0)}$ & $\frac{25}{(57)}$ & $\frac{45}{(94)}$ & $\frac{21}{(65)}$ \\
\hline C & $\frac{47}{(86)}$ & $\frac{-3}{(23)}$ & $\frac{5}{(35)}$ & $\frac{-32}{(0)}$ & $\frac{-6}{(23)}$ & $\frac{55}{(86)}$ & $\frac{6}{(42)}$ \\
\hline $\mathrm{D}$ & $\frac{75}{(128)}$ & $\frac{25}{(57)}$ & $\frac{35}{(85)}$ & $\frac{-33}{(0)}$ & $\frac{25}{(57)}$ & $\frac{84}{(128)}$ & $\frac{30}{(76)}$ \\
\hline E & $\frac{43}{(90)}$ & $\frac{11}{(40)}$ & $\frac{21}{(60)}$ & $\frac{-33}{(0)}$ & $\frac{8}{(40)}$ & $\frac{50}{(90)}$ & $\frac{13}{(53)}$ \\
\hline $\mathrm{F}$ & $\frac{5}{(40)}$ & $\frac{-25}{(40)}$ & $\frac{-20}{(0)}$ & $\frac{-33}{(0)}$ & $\frac{-31}{(0)}$ & $\frac{16}{(0)}$ & $\frac{-17}{(7)}$ \\
\hline G & $\frac{74}{(180)}$ & $\frac{46}{(80)}$ & $\frac{60}{(120)}$ & $\frac{-33}{(0)}$ & $\frac{45}{(80)}$ & $\frac{85}{(180)}$ & $\frac{41}{(107)}$ \\
\hline $\mathrm{H}$ & $\frac{-7}{(50)}$ & $\frac{12}{(40)}$ & $\frac{22}{(60)}$ & $\frac{-32}{(0)}$ & $\frac{11}{(40)}$ & $\frac{7}{(50)}$ & $\frac{2}{(40)}$ \\
\hline I & $\frac{89}{(130)}$ & $\frac{10}{(40)}$ & $\frac{22}{(60)}$ & $\frac{-32}{(0)}$ & $\frac{9}{(40)}$ & $\frac{97}{(130)}$ & $\frac{25}{(67)}$ \\
\hline $\mathrm{J}$ & $\frac{-11}{(0)}$ & $\frac{-10}{(0)}$ & $\frac{-15}{(0)}$ & $\frac{-29}{(0)}$ & $\frac{-28}{(0)}$ & $\frac{-25}{(0)}$ & $\frac{-17}{(0)}$ \\
\hline
\end{tabular}

of fertilization with an average annual dose of $30 \mathrm{~kg}$ $\mathrm{P}_{2} \mathrm{O}_{5} \cdot \mathrm{ha}^{-1}$ had the balanced balance and combination of fertilization with an annual average dose of $60 \mathrm{~kg}$ $\mathrm{P}_{2} \mathrm{O}_{5} \cdot \mathrm{ha}^{-1}$ respectively $120 \mathrm{~kg} \mathrm{P}_{2} \mathrm{O}_{5} \cdot$ ha $^{-1}$ showed the positive balance with strong surplus.

The most $\mathrm{P}$ balance surplus was after the cultivation of sugar beet and silage maize for combination I. On the contrary, the largest uptake P from the soil was observed when the alfalfa was growing without application of $\mathrm{P}$ in both fertilizations. Vos (1996) calculated the negative $\mathrm{P}$ balance for potato $\left(-7 \mathrm{~kg} \cdot \mathrm{ha}^{-1}\right)$ at the total $\mathrm{P}$ input $37 \mathrm{~kg} \cdot \mathrm{ha}^{-1}$ and positive $\mathrm{P}$ balance for sugar beet (11 kg.ha $\left.{ }^{-1}\right)$ at the total P input $32 \mathrm{~kg} \cdot \mathrm{ha}^{-1}$ and for spring wheat $\left(9 \mathrm{~kg} \cdot \mathrm{ha}^{-1}\right)$ at the total $\mathrm{P}$ input $34 \mathrm{~kg} \cdot \mathrm{ha}^{-1}$ in the Netherland. In our trial phosphorus offtake and input were balanced at the cultivation of spring barley, winter wheat and alfalfa with oat underseeding in combination A (Tab. III). Effective $\mathrm{P}$ doses for balanced balance were $23 \mathrm{~kg}$ P.ha-1 in mineral fertilization and $0 \mathrm{~kg}$ P.ha $^{-1}$ in FYM fertilization for spring barley and winter wheat and $35 \mathrm{~kg}$ P.ha ${ }^{-1}$ in mineral fertilization and $0 \mathrm{~kg}$ P.ha ${ }^{-1}$ in FYM fertilization for alfalfa with oat underseeding. $\mathrm{P}$ balance was balanced in combination $\mathrm{H}$ with applied doses $50 \mathrm{~kg}$ P.ha-1 in mineral fertilization and without FYM for silage maize and in combination $\mathrm{F}$ without mineral fertilization and
$40 \mathrm{~kg}$ P.ha $^{-1}$ in FYM for sugar beet. Čermák and Smatanová calculated $\mathrm{P}$ nutrient balance in the long-term field experiment from 1972 to 2005 for crop rotation contained 25 percent of root crops, 50 percent of cereals and 25 percent of fodder crops in sugar beet and potato growing area of the Czech Republic. They confirmed P offtake and input was balanced at low levels of $\mathrm{P}$ fertilization and they recommended effective average annual rates $13 \mathrm{~kg}$ of $\mathrm{P}$ for obtaining adequate yields and preservation of suitable contents of nutrients in the soil.

We calculated P offtake of main crops on 1 tonne. The average $\mathrm{P}$ offtake was $3.8 \mathrm{~kg}$ P.t $\mathrm{t}^{-1}$ for spring barley, $3.1 \mathrm{~kg}$ P.t-1 for winter wheat, $0.6 \mathrm{~kg}$ P.t $^{-1}$ for alfalfa and silage maize and $0.7 \mathrm{~kg}$ P.t $\mathrm{t}^{-1}$ for sugar beet. Klír et al. (2007) showed the similar values of the average $\mathrm{P}$ offtake for crops in the soil and climate conditions of the Czech Republic.

The impact of $\mathrm{P}$ fertilization on the yield of agricultural crops was found out. $\mathrm{P}$ fertilization had the positive effect on the yield of winter wheat, silage maize and alfalfa with oat underseeding. Sugar beet and spring barley did not show significant yield reaction on $\mathrm{P}$ fertilization level. Correlation coefficients between fertilization and yield are shown in Tab. IV. Very interesting relationship were found between the content of $\mathrm{P}$ in plant dry matter and its total yield for all crops. 


\begin{tabular}{lccc}
\hline \multirow{2}{*}{ Crops } & \multirow{2}{*}{$\begin{array}{c}\text { Correlation coefficient }(\mathrm{r}) \\
{ }^{*} \mathrm{p}<0.05\end{array}$} \\
\cline { 3 - 4 } sugar beet & 280 & -0.02 & $0.59^{*}$ \\
spring barley & 504 & 0.03 & $0.87^{*}$ \\
alfalfa with oat underseeding & 280 & $0.37^{*}$ & $0.94^{*}$ \\
alfalfa without fertilization & 224 & - & $0.89^{*}$ \\
winter wheat & 447 & $0.29^{*}$ & $0.75^{*}$ \\
silage maize & 224 & $0.34^{*}$ & $0.75^{*}$ \\
\hline
\end{tabular}

*the values are significant at $\mathrm{p}<0.05$

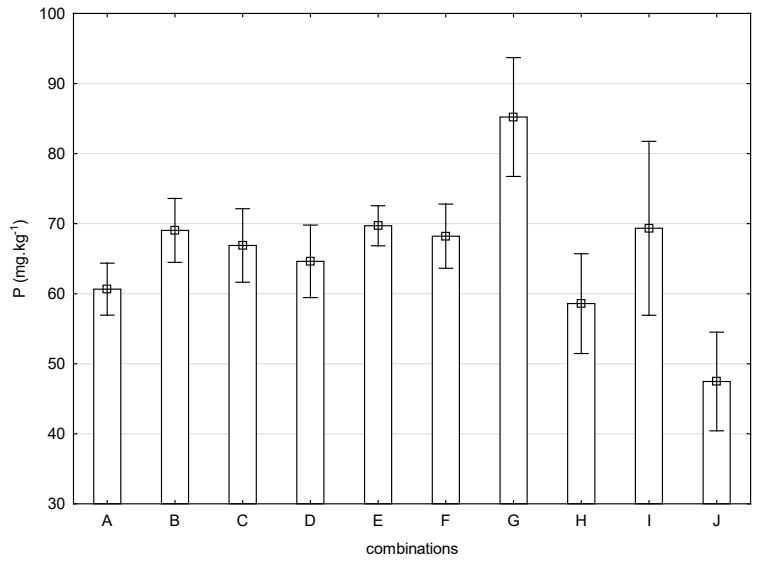

A

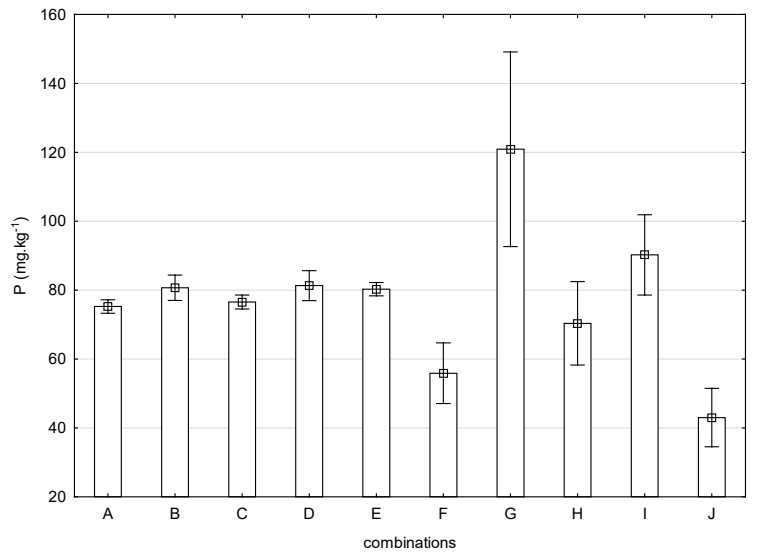

C

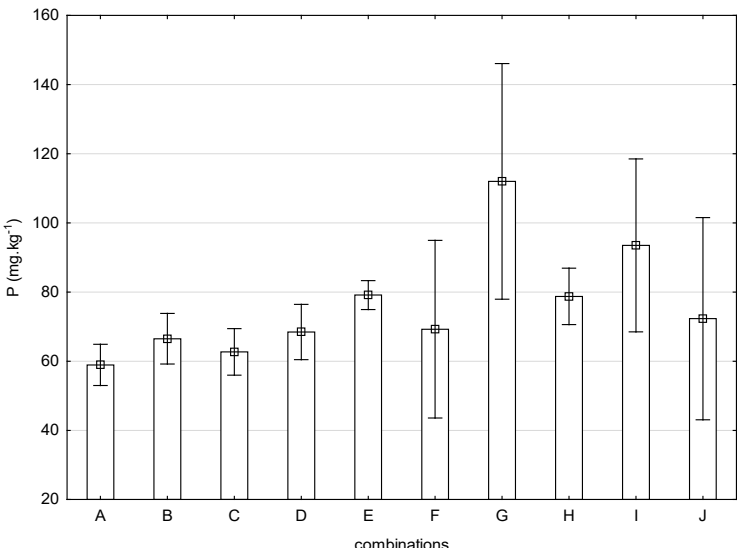

B

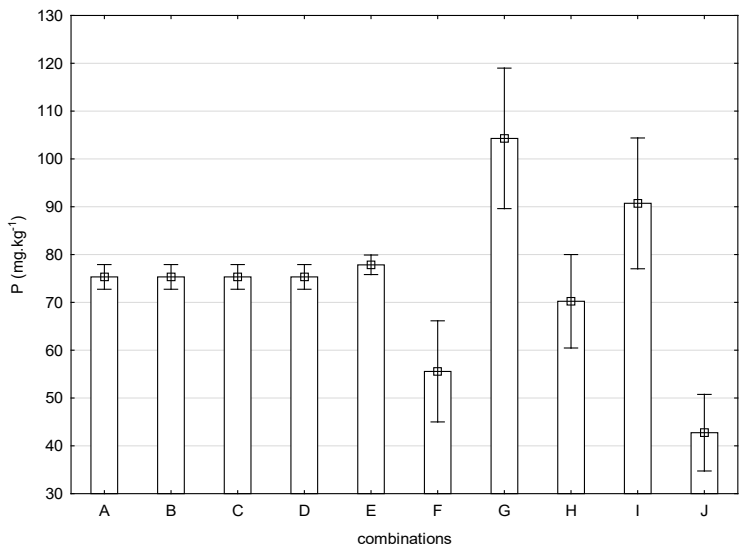

$\mathrm{D}$

1: Average available P content ( $\left.\mathrm{mg} \cdot \mathrm{kg}^{-1}\right)$ in soil during four 8-year crop rotations in all combinations A) 1980-1987, B) 1988-1995, C) 1996-2003, D) 2003-2011; bars represent standard error

$\mathrm{P}$ contents in plants showed very high positive correlation to yield (Tab. IV).

According to obtained data, P level in the soil for each combination of factors did not significantly change during observed years (Fig. 1). Fig. 1 shows that the combination $\mathrm{G}$ had the most P content in the soil from the beginning of experiment to 2011 in contrast to combination J with the smallest $\mathrm{P}$ content in all observed years.
Data about $\mathrm{P}$ offtake for crops could be use to evaluate economically and effective doses of $\mathrm{P}$ fertilizer that provide balanced yields without $\mathrm{P}$ losses. The lowest $\mathrm{P}$ offtake was found out in combination J for sugar beet, spring barley, winter wheat and alfalfa without fertilization. The highest P offtake was found out in combination $G$ for spring barley, winter wheat, alfalfa without fertilization and in combination I for sugar beet. The total yield 
of crops is influenced by many other external and growing factors. Application of medium and low doses of $\mathrm{P}$ in mineral and FYM fertilization seems to be the most economical in soils with suitable to high P supply. Medium and low P doses maintain a balanced P balance in soil with a small modification of $\mathrm{P}$ fertilization doses for subsequent crops.

\section{CONCLUSION}

We received detailed information about $P$ nutrient balance from long-term field experiments includes 10 combination of fertilization. The results showed that soil with good P supply is a sufficient to achieving an optimal P balance based on application of specific rates fertilization for every crop. We concluded that effective annual rates of $\mathrm{P}$ are $23 \mathrm{~kg}$ in mineral fertilization for spring barley and winter wheat; $35 \mathrm{~kg}$ in mineral fertilization for alfalfa with oat underseeding; $50 \mathrm{~kg}$ P in mineral fertilization for silage maize and $40 \mathrm{~kg} P$ in farmyard manure for sugar beet. A long-term absence of $\mathrm{P}$ fertilization has the negative effect on the balance of $\mathrm{P}$ and may lead to reduce yield of all growing crops. This information should mainly contribute to sensitive soil management and environmental protection. Thus, farmers can optimize all of the production inputs into the field exactly where they are needed, based on detailed knowledge about the yield, nutrient content in dry matter of plants, soil properties of particular field.

\section{Acknowledgements}

This study was supported by the Ministry of Agriculture of the Czech Republic, project No. RO-0417.

\section{REFERENCES}

BEEGLE, D. and LANYON, L. 2015. Phosphorus balance. USDA-NRCS. Available at: https://sera17dotorg files.wordpress.com/2015/02/bmp_phosphorus_balance.pdf [Accessed: 2015, April 20].

BUSMAN, L., LAMB, J., RANDALL, G. et al. 2002. The nature of phosphorus in soils. [Online]. Available at: http://www.extension.umn.edu/agriculture/nutrient-management/phosphorus/the-nature-ofphosphorus/ [Accessed: 2017, May 4].

CHATER, M. and MATTINGLY, G. E. G. 1980. Changes in organic phosphorus contents of soils from long-continued experiments at Rothamsted and Saxmundham. In: Rothamsted Research Annual Report for 1979. Part 2. Rothamsted Research, pp. 41-61.

COCHRAN, W. G. and COX, G. M. 1957. Experimental Designs. New York: John Wiley and Sons.

ČERMÁK, P., DVORSKÝ, J., KLÍR, J. et al. 2007. Methodical handbook. Nutrients balance in organic farm [in Czech: Metodická pomůcka. Bilance živin v ekologicky hospodařícím podniku]. Náměšt nad Oslavou: Zera - Zemědělská a ekologická regionální agentura.

ČERMÁK, P. and SMATANOVÁ, M. 2012. Nutrient balance in long-term field experiments in the Czech Republic. In: E-ifc No. 31 - Research Findings. Zug: International Potash Institute.

EKHOLM, P., TURTOLA, E., GRÖNROOS, J. et al. 2005. Phosphorus loss from different farming systems estimated from soil surface phosphorus balance. Agriculture, Ecosystems and Environment, 110(3-4): 266-278.

EUROSTAT. 2017. Archive: Phosphorus balance in agriculture.Eurostat. [Online]. Available at: http:// ec.europa.eu/eurostat/statisticsexplained/index.php?title=Archive:Phosphorus_balance_in_ agriculture\&oldid=243931 [Accessed: 2015, May 2].

HALBERG, N. 1999. Indicators of resource use and environmental impact for use in a decision aid for Danish livestock farmers. Agriculture, Ecosystems and Environment, 76(1): 17-30.

HOODA, P. S., TRUESDALE, V. W., EDWARDS, A. C. et al. 2001. Manuring and fertilization effects on phosphorus accumulation in soils and potential environmental implications. Adv. Environ. Res., 5(1): $13-21$.

HRAŠKO, J., ČERVENKA, L., FACEK, Z. et al. 1962. Soil Analyses. Bratislava: SVPL.

HU, Y., HAO, M., WEI, X. et al. 2016. Contribution of fertilisation, precipitation, and variety to grain yield in winter wheat on the semiarid Loess Plateau of China. Acta Agriculturae Scandinavica, Section B - Soil \& Plant Science, 66(5): 406-416.

KLÍR, J. et al. 2007. Framework methodology of plant nutrition and fertilization [in Czech: Rámcová metodika výživy rostlin a hnojeni]. 2nd Updated Edition. Výzkumný ústav rostlinné výroby, v.v.i.

MACHÁČEK, V. and KUNZOVÁ, E. 2016. The balance of phosphorus in the long-term field experiment as affected by application of cattle manure [in Czech: Bilance fosforu v dlouhodobém pokusu hnojeném statkovým hnojivem typu skot]. Agromanuál, 11(7): 54-55. 
MADARAS, M. and LIPAVSKÝ, J. 2009. Interannual dynamics of available potassium in a long-term fertilization experiment. Plant soil environ., 55(8): 334-343.

MAGDID, J. and NIELSEN, N. E. 1992. Seasonal variation in organic and inorganic phosphorus fractions of temperature-climate sandy soils. Plant Soil, 144: 155-165.

O'HALLORAN, I. P. O., STEWART, J. W. B. and KASCHANOSKI, R. G. 1987. Influence of texture and management practices on the forms and distribution of soil phosphorus. Can. J. Soil Sci., 67: 147163.

OTT, C. and RECHBERGER, H. 2012. The European phosphorus balance. Resources, Conservation and Recycling, 60: 159-172.

RACLAVSKÁ, H., KUCHAŘOVÁ, J. and PLACHÁ, D. 2008. Documents for the implementation of the PRTR Protocol - Overview of methods and identification of substances monitored under the protocol of pollutant leakage and transfer of pollutants into the soil [in Czech: Podklady k provádění Protokolu o PRTR - Přehled metod a identifikace látek sledovaných podle Protokolu o registrech úniků a přenosů znečištujících látek v únicích do půdy]. Praha: VŠB, MŽP.

SHI, L., SHEN, M., LU, C. et al. 2015. Soil phosphorus dynamic, balance and critical P values in longterm fertilization experiment in TIHU Lake region, China. Journal of Integrative Agriculture, 14(12): 2446-2455.

STEINSHAM, H., THUEN, E., BLEKEN, M. A. et al. 2004. Utilization of nitrogen and phosphorus in an organic dairy farming system in Norway. Agriculture, Ecosystems, 104(3): 509-522.

STEWART, J. W. B. and TIESSEN, H. 1987. Dynamics of soil organic phosphorus. Biogeochemistry, 4: 41-60.

TATE, K. R., SPEIR, T. W., ROSS, D. J. et al. 1991. Temporal variations in some plant and soil P pools in two pasture soils of widely different P status. Plant Soil, 132(2): 219-232.

USHERWOOD, N. R. and SEGARS, W. I. 2001. Nitrogen interactions with phosphorus and potassium for optimum crop yield, nitrogen use effectiveness, and environmental stewardship. The Scientific World Journal, 1(Suppl. 2): 57-60.

VOPLAKAL, K. 2001. Phosphorus in soil [in Czech: Fosfor v půdě]. Úroda, 49: 24-27.

VOS, J. 1996. Input and offtake of nitrogen, phosphorus and potassium in cropping systems with potato as a main crop and sugar beet and spring wheat as subsidiary crops. European Journal of Agronomy, 5: 105-114.

Contact information

Štěpánka Matějková: matejkova@vurv.cz (corresponding author)

Markéta Mayerová: mayerova@vurv.cz

Lenka Odstrčilová: lenka.odstrcilova@vurv.cz

Jitka Kumhálová: kumhalova@tf.czu.cz 
